\title{
PENGARUH LIKUIDITAS, LEVERAGE, DAN KEPEMILIKAN INSTITUSIONAL TERHADAP FINANCIAL DISTRESS PADA PERUSAHAAN PROPERTY DAN REAL ESTATE
}

\author{
Ni Made Inten Septiani ${ }^{1}$ \\ I Made Dana ${ }^{2}$ \\ ${ }^{1,2}$ Fakultas Ekonomi dan Bisnis Universitas Udayana (Unud), Bali, Indonesia \\ e-mail: intenseptiani@yahoo.com
}

\begin{abstract}
ABSTRAK
Penelitian ini bertujuan untuk mengetahui pengaruh likuiditas, leverage, dan kepemilikan institusional dalam memprediksi kondisi financial distress pada perusahaan property dan real estate di Bursa Efek Indonesia (BEI) periode 2013-2017. Teknik pengambilan sampel yang digunakan yaitu purposive sampling dengan jumlah sampel terpilih sebanyak 36 perusahaan. Jumlah sampel yang digunakan yaitu sebanyak 6 perusahaan dalam kategori mengalami financial distress dan 30 perusahaan dalam kategori tidak mengalami financial distress.Hasil penelitian dengan menggunakan logistic regression menunjukkan bahwa likuiditas yang diukur dengan current ratio berpengaruh positif signifikan terhadap financial distress. Leverage yang diukur dengan debt to asset ratio (DAR) dan kepemilikan institusional berpengaruh negatif signifikan terhadap financial distress. Secara keseluruhan, ketepatan klasifikasi pada model regresi ini dalam pengelompokkan perusahaan subsektor property dan real estate yang mengalami financial distress dan perusahaan yang tidak mengalami financial distress adalah sebesar $87,2 \%$.
\end{abstract}

Kata kunci: financial distress, likuiditas, leverage, kepemilikan institusional

\section{ABSTRACT}

This study aims to determine the effect of liquidity, leverage, and institutional ownership in predicting financial distress conditions in property and real estate companies on the Indonesia Stock Exchange (IDX) for the period 2013-2017. The sampling technique used was purposive sampling with a number of selected samples of 36 companies. The number of samples used was as many as 6 companies in the category of experiencing financial distress and 30 companies in the category did not experience financial distress. The results of the study using logistic regression show that liquidity measured by the current ratio has a significant positive effect on financial distress. Leverage as measured by the debt to asset ratio (DAR) and institutional ownership has a significant negative effect on financial distress. Overall, the accuracy of the classification in this regression model in the grouping of property and real estate sub-sector companies that experienced financial distress and companies that did not experience financial distress was $87.2 \%$.

Keywords: financial distress, liquidity, leverage, institutional ownership 


\section{PENDAHULUAN}

Kondisi ekonomi yang selalu mengalami perubahan telah mempengaruhi kegiatan dan kinerja perusahaan, baik perusaahan kecil maupun perusahaan besar. Persaingan perusahaan satu dengan yang lainnya semakin lama semakin ketat, sehingga menyebabkan biaya yang akan dikeluarkan oleh perusahaan juga semakin tinggi. Apabila perusahaan tidak mampu bersaing maka perusahaan akan mengalami kerugian dan pada akhirnya mengakibatkan perusahaan mengalami kebangkrutan (financial distress).

Perusahaan yang dinilai baik secara keuangan belum tentu benar- benar baik dan bisa dijamin kelangsungan usahanya, bisa saja setahun kemudian dinyatakan bangkrut. Kebangkrutan disebabkan oleh salah satunya karena ketidakmampuan perusahaan yang bersangkutan untuk membayar kewajiban yang telah jatuh tempo. Suatu perusahaan dianggap mengalami kebangkrutan atau kegagalan keuangan ketika tingkat pengembalian yang diperoleh perusahaan lebih kecil dari total biaya yang harus dikeluarkannya dalam jangka panjang (Pulungan, 2017).

Penyebab financial distress yaitu faktor ketidakcukupan modal atau kekurangan modal, besarnya beban utang dan bunga serta menderita kerugian (Afriyeni, 2012). Model financial distress perlu untuk dikembangkan, penting bagi suatu perusahaan untuk mengetahui kondisi financial distress agar perusahaan waspada dan melakukan tindakan dalam rangka melindungi aset-aset perusahaan agar tidak mengalami kebangkrutan (Liana \& Sutrisno, 2014). Perusahaan dianggap mengalami financial distress ketika salah satu dari kondisi ini terpenuhi (1) perusahaan yang mengalami rugi selama tiga tahun berturut-turut 
atau lebih (2) perusahaan yang memiliki arus kas negatif selama tiga tahun atau lebih (Lakshan \& Wijekoon, 2013).

Kebangkrutan perusahaan akan mengakibatkan berbagai kerugian baik bagi pemegang saham, karyawan dan perekonomian nasional (Al-khatib \& Al-Horani, 2012). Bhunia et al. (2011) menyatakan bahwa adanya financial distress pada perusahaan dapat dapat mengurangi efisiensi manajemen. Kondisi keuangan yang mengalami financial distress menjadi salah satu hal yang harus diperhatikan oleh perusahaan. Perusahaan yang mengalmi financial distress dapat menyebabkan perusahaan tidak memiliki kemampuan untuk tetap menjaga keberlangsungan usahanya, dan apabila tidak ditanggulangi dengan tepat maka perusahaan akan mengalami kebangkrutan.

Perusahaan property dan real estate adalah perusahaan yang bergerak dalam bidang pemenuhan konsumen atas rumah dan property.Investasi pada industri properti pada umumnya bersifat jangka panjang dan akan tumbuh sejalan dengan pertumbuhan ekonomi (supply tanah besifat tetap sedangkan demand akan selalu lebih besar seiring dengan pertambahan jumlah penduduk). Terjadinya krisis keuangan global yang bermula pada tahun 2008 silam yang terjadi di negara Amerika Serikat utamanya diawali dari jatuhnya industri properti dan akhirnya berdampak pula pada wilayah Asia tidak terkecuali di Indonesia. Hal ini mengakibatkan beberapa perusahaan property dan real estate di Bursa Efek Indonesia mengalami kebangkrutan dan keadaan bisnis property dan real estate dalam keadaan waspada. Ini dikarenakan adanya gejolak ekonomi yang terjadi di 
indonesia. Gejolak tersebut terkait dengan kondisi suku bunga bank yang relatif tinggi akibat melemahnya rupiah terhadap dollar Amerika Serikat.

Beberapa tahun belakangan ini perusahaan subsektor property dan real estate selalu ada yang delisting dari Bursa Efek Indonesia. Pada tahun 2011 New Century Development Tbk mengalami delisting dari Bursa Efek Indonesia. Pada tahun 2012 perusahaan Surya Inti Permata Tbk juga mengalami delisting dari Bursa Efek Indonesia. Pada tahun 2013 giliran perusahaan Panca Wirasakti Tbk yang mengalami delisting dari Bursa Efek Indonesia (Abadi \& Ghoniyah, 2016). Banyak faktor yang menyebabkan perusahaan harus terdelisting dari Bursa Efek Indonesia, salah satunya meliputi penurunan kinerja perusahaan yang ditandai dengan ketidakcukupan modal, besarnya beban utang, dan bunga. Faktor lainnya yaitu saham perusahaan tidak likuid yang artinya saham jarang ditransaksikan atau sepi peminat.

Tabel 1.

Nilai EPS Negatif Subsektor Perusahaan Property dan Real Estate 2013-2017

\begin{tabular}{ccccccc}
\hline \multirow{2}{*}{ No } & \multirow{2}{*}{ Nama Perusahaan } & $\mathbf{2 0 1 3}$ & $\mathbf{2 0 1 4}$ & $\mathbf{2 0 1 5}$ & $\mathbf{2 0 1 6}$ & $\mathbf{2 0 1 7}$ \\
\hline 1 & PT Bukit Darmo Property Tbk & $-8,65$ & 1,05 & $-4,13$ & $-4,24$ & $-6,32$ \\
2 & PT Cowell Development Tbk & 10,00 & 33,95 & $-36,68$ & $-4,81$ & $-14,17$ \\
3 & PT Bakrieland Development Tbk & $-5,31$ & 10,91 & $-16,64$ & $-12,57$ & $-6,20$ \\
4 & PT Eureka Prima Jakarta Tbk & 0,35 & $-1,68$ & $-0,77$ & 0,07 & $-2,38$ \\
5 & PT Metro Realty Tbk & $-8,91$ & $-4,70$ & $-20,07$ & $-10,15$ & $-418,25$ \\
6 & PT Nirvana Development Tbk & 0,35 & $-6,02$ & $-1,26$ & $-1,41$ & $-0,35$ \\
7 & PT Ristia Bintang Mahkotasejati Tbk & $-42,80$ & 9,19 & $-9,44$ & $-20,55$ & 44,43 \\
\hline \multicolumn{5}{l}{ Sumber:IDX, 2017} \\
\multicolumn{5}{c}{}
\end{tabular}

Perusahaan yang sedang mengalami financial distress dapat dilihat dengan berbagai cara, salah satunya yaitu dari rasio Earning Per Share (EPS). Data EPS banyak digunakan untuk mengevaluasi kinerja operasi dan profitabilitas perusahaan. EPS yang positif secara terus-menerus setiap periodenya 
mengindikasikan bahwa perusahaan memiliki petumbuhan yang baik dimasa mendatang. Sebaliknya perusahaan yang memiliki nilai EPS negatif dapat dikategorikan mengalami kondisi financial distress karena menandakan bahwa perusahaan sedang mengalami rugi usaha akibat pendapatan yang diterima pada periode tersebut lebih kecil dari biaya yang dikeluarkan (Sastriana, 2013).

Berdasarkan tabel 1 terdapat tujuh perusahaan pada subsektor property dan real estate yang mengalami EPS negatif 2 tahun berturut-turut atau lebih yang mengindikasikan bahwa perusahaan tersebut diatas sedang mengalami financial distress. Investor akan mempertimbangkan investasinya pada perusahaan yang memiliki nilai EPS negatif karena dianggap memiliki pertumbuhan yang buruk akibat pendapatan yang diterima lebih kecil dari biaya yang dikeluarkan sehingga perusahaan mengalami kerugian di tahun tersebut.

Tabel 2.

Rata-rata Harga Penutupan Saham Tahunan Subsektor PerusahaanProperty dan Real Estate 2013-2017

\begin{tabular}{cc}
\hline Tahun & Rata-rata Harga Penutupan Saham (dalam rupiah) \\
\hline 2013 & 1.148 \\
2014 & 1.542 \\
2015 & 1.487 \\
2016 & 1.616 \\
2017 & 1.687 \\
\hline
\end{tabular}

Sumber:IDX, 2017

Rata-rata harga penutupan saham tahunan perusahaan subsektor property dan real estate dapat dikatakan fluktuatif pada tahun 2013 sampai dengan 2015, dan mengalami peningkatan pada tahun 2016 dan 2017 jika dilihat dari tabel 2 Dilihat dari rata-rata harga penutupan saham pada tabel 2, mengidentifikasikan bahwa kinerja perusahaan subsektor property dan real estate mengalami peningkatan dan penurunan periode 2013-2017. Naik turunnya harga saham 
disebabkan oleh turunnya harga komoditi di subsektor property dan real estate, berkurangnya permintaan terhadap komoditi di subsektor property dan real estate untuk negara tujuan ekspor karena dampak perlambatan ekonomi negara tujuan ekspor. Adapun faktor lain yang dapat mempengaruhi naik turunnya harga saham subsektor property dan real estate seperti kinerja perusahaan, kinerja industri, ekonomi makro, serta fluktuasi kurs rupiah.

Laporan keuangan dapat dijadikan dasar untuk mengukur kesehatan suatu perusahaan melalui rasio-rasio keuangan yang ada. Rasio keuangan bermanfaat dalam memprediksi kesulitan keuangan bisnis untuk periode satu sampai lima tahun sebelum bisnis tersebut benar-benar bangkrut. Maka melalui analisis laporan keuangan akan diperoleh rasio-rasio keuangan perusahaan yang menggambarkan tentang kondisi keuangan perusahaan, rasio-rasio keuangan inilah yang merupakan indikator yang digunakan untuk memprediksi terjadinya financial distress.

Menurut Andre \& Taqwa (2014), secara umum rasio-rasio seperti profitabilitas, likuiditas, leverage dan cakupan arus kas berlaku sebagai indikator yang paling signifikan dalam memprediksi kesulitan keuangan maupun kebangkrutan. Perusahaan yang menghindari financial distress adalah perusahaan yang mampu menunjukkan kinerja keuangan yang baik yang dapat dilihat dari rasio keuangannya (Kristanti et al., 2016). Rasio keuangan yang digunakan untuk mengukur financial distress suatu perusahaan pada penelitian ini yaitu raiso Likuiditas dan Leverage. Bagian dari corporate governance yang mampu memprediksi financial distress juga digunakan pada penelitian ini yatu 
Kepemilikan Institusional. Kepemilikan institusional adalah bagian dari struktur kepemilikan dalam perusahaan. Adanya kepemilikan saham oleh investor institusional yang tinggi maka pemegang saham institusional dapat menggantikan atau memperkuat fungsi monitoring dari dewan dalam perusahaan (Helena \& Saifi, 2018).

Rasio likuiditas dapat digunakan untuk memprediksi terjadinya financial distress. Rasio likuiditas (liquidity ratio) adalah kemampuan suatu perusahaan memenuhi kewajiban jangka pendeknya secara tepat waktu (Irham, 2014:121). Likuiditas menunjukkan kemampuan suatu entitas dalam menutupi kewajiban lancar perusahaan dengan memanfaatkan aktiva lancarnya. Perusahaan dapat dikatakan likuid apabila perusahaan tersebut bisa menyelesaikan kewajiban jangka pendeknya saat jatuh tempo, tetapi apabila perusahaan tidak bisa menyelesaikan kewajiban jangka pendeknya saat jatuh tempo maka perusahaan tersebut dikatakan tidak likuid atau illikuid.

Perusahaan yang memiliki tingkat likuiditas yang tinggi mengindikasikan perusahaan memiliki sejumlah aset lancar yang siap untuk membayar utang jangka pendeknya sehingga perusahaan tersebut dapat terhindari dari kondisi financial distress(Carolina dkk., 2017).Rasio likuiditas pada penelitian ini diukur dengan Current Ratio. Current ratio yaitu rasio yang membagi jumlah aset lancar (current assets) dengan utang lancar (current liabilities) perusahaan (Widhiari \& Merkusiwati, 2015). Semakin tinggi current ratio berarti semakin besar kemampuan perusahaan untuk memenuhi kewajiban financial jangka pendek. 
Penelitian Pulungan (2017), Ufo (2015), Yudiawati \& Indriani (2016), Khaliq et al. (2014), dan Triwahyuningtias \& Muharam (2012) menunjukkan bahwa Likuiditas yang diukur dengan Current Ratio berpengaruh positif signifikan terhadap financial distress. Penelitian H. Setiawan \& Amboningtyas (2018), Darminto \& Handayani (2013), Nindita et al. (2014), Widhiari \& Merkusiwati (2015), Hidayat \& Meiranto (2014) menunjukkan Likuiditas yang diukur dengan current ratio memiliki pengaruh negatif signifikan terhadap financial distress.

Adapun rasio keuangan yang dapat digunakan untuk mengukur financial distress selain rasio likuiditas yaitu rasio leverage. Rasio leverage mengukur seberapa besar perusahaan dibiayai dengan utang. Penggunaan utang yang terlalu tinggi dapat membahayakan perusahaan karena akan masuk dalam kategori extreme leverage (utang ekstrem) yaitu perusahaan berada dalam tingkat utang yang tinggi dan sulit untuk melepaskan beban utang tersebut (Irham, 2015:127). Rasio ini diukur dengan Debt to Assets Ratio (DAR). Apabila suatu perusahaan pembiayaannya lebih banyak menggunakan utang, hal ini berisiko akan terjadi kesulitan pembayaran di masa yang akan datang akibat utang lebih besar dari hasil yang dimiliki. Jika keadaan ini tidak dapat diatasi dengan baik, potensi terjadinya financial distress pun semakin besar.

Penelitian Saleh \& Sudiyatno (2013), Lee et al. (2010), Andre \& Taqwa (2014), Hidayat \& Meiranto (2014), Ong et al. (2011), Jiming \& Weiwei (2011), Waqas \& Md-rus (2018), dan Simanjuntak (2017) menunjukkan Leverage yang diukur dengan Debt to Assets Ratio (DAR) memiliki pengaruh positif signifikan 
terhadap financial distress. Berbeda dengan penelitian Silalahidkk. (2018) yang melakukan penelitian pada perusahaan subsektor transportasi yang terdaftar di BEI Periode 2013-2016 menyatakan bahwa leverage yang diukur dengan debt to assets ratio berpengaruh negatif signifikan terhadap financial distress. Penelitian Harianti (2018) dan Alifiah et al. (2013) juga menyatakan bahwa leverage yang diukur dengan DAR berpengaruh negatif dan signifikan terhadap financial distress.

Kepemilikan institusional dapat mempengaruhi financial distress selain dari rasio likuiditas dan leverage. Suatu perusahaan berada pada posisi kesulitan keuangan (financial distress) banyak dipengaruhi oleh struktur kepemilikannya. Stuktur kepemilikan tersebut menjelaskan komitmen dari pemiliknya untuk menyelamatkan perusahaan. Kepemilikan institusional dalam suatu perusahaan terkait dengan fungsi monitoring dimana para investor institusional akan lebih ketat dalam melakukan pengawasan terhadap manajemen serta dapat menimbulkan sikap yang hati-hati terhadap manajemen menjalankan usaha dan memilih peluang investasi yang positif (Laurenzia \& Sufiyati, 2015). Kemungkinan terjadinya kerugian pada perusahaan yang dapat menyebabkan financial distressakan semakin kecil apabila adanya pengawasan yang dilakukan semakin tinggi serta menurunnya biaya keagenan yang dikeluarkan.

Penelitian Laurenzia \& Sufiyati (2015) dan Lieu et al. (2008) yang menyatakan bahwa kepemilikan institusional berpengaruh positif signifikan terhadap financial distress. Penelitian Cinantya \& Merkusiwati (2015), Hanifah \& Purwanto (2013), Fathonah (2016), Sujana dkk. (2017), Fan et al. (2013), dan 
Helena \& Saifi (2018) yang menyatakan bahwa kepemilikan institutional berpengaruh negatif signifikan terhadap financial distress. Kepemilikan institusional yang tinggi akan lebih terhindar dari kondisi kesulitan keuangan disebabkan karena pengawasan terhadap manajemen dalam melaksanakan kegiatan operasionalnya dapat dilakukan oleh pihak institusi. Semakin besar proporsi kepemilikan institusional suatu perusahaan, maka semakin kecil kemungkinan perusahaan tersebut mengalami financial distress.

Likuiditas perusahaan menunjukkan kemampuan perusahaan dalam mendanai operasional perusahaan dan melunasi kewajiban jangka pendek perusahaan. Apabila perusahan mampu mendanai dan melunasi kewajiban jangka pendeknya dengan baik maka potensi perusahaan mengalami financial distress akan semakin kecil. Penelitian H. Setiawan \& Amboningtyas (2018), Darminto \& Handayani (2013), Nindita et al. (2014), Widhiari \& Merkusiwati (2015), Hidayat \& Meiranto (2014) menunjukkan Likuiditas yang diukur dengan current ratio memiliki pengaruh negatif signifikan terhadap financial distress. Berdasarkan landasan teori dan hasil penelitian sebelumnya, maka hipotesis pertama dalam penelitian ini adalah sebagai berikut:

$\mathrm{H}_{1}$ : Likuiditas berpengaruh negatif dan signifikan terhadap terjadinya financial distress perusahaan.

Analisis leverage diperlukan untuk mengukur kemampuan perusahaan dalam membayar utang (jangka pendek dan jangka panjang). Apabila suatu perusahaan pembiayaannya lebih banyak menggunakan utang, hal ini berisiko akan terjadi kesulitan pembayaran di masa yang akan datang akibat utang lebih besar dari aset yang dimiliki. Jika keadaan ini tidak dapat diatasi dengan baik, 
potensi terjadinya financial distress pun semakin besar. Penelitian Saleh \& Sudiyatno (2013), Lee et al. (2010), Andre \& Taqwa (2014), Hidayat \& Meiranto (2014), Ong et al. (2011), Jiming \& Weiwei (2011), Waqas \& Md-rus (2018), dan Simanjuntak (2017) menunjukkan Leverage yang diukur dengan Debt to Assets Ratio (DAR) memiliki pengaruh positif terhadap financial distress. Berdasarkan landasan teori dan hasil penelitian sebelumnya, maka hipotesis kedua dalam penelitian ini adalah sebagai berikut:

$\mathrm{H}_{2}$ : Leverage berpengaruh positif dan signifikan terhadap terjadinya financial distress perusahaan.

Kepemilikan institusional yang besar (lebih dari 5\%) mengindikasikan kemampuan memonitor perusahaan. Semakin besar kepemilikan institusional maka semakin efisien pemanfaatan aktiva perusahaan, sehingga potensi kesulitan keuangan dapat diminimalkan (Hanifah \& Purwanto, 2013). Hal ini dikarenakan semakin besar kepemilikan institusional akan semakin besar monitoring yang dilakukan terhadap perusahaan yang pada akhirnya akan mampu mendorong semakin kecilnya potensi kesulitan keuangan yang mungkin terjadi dalam perusahaan. Penelitian Cinantya \& Merkusiwati (2015), Hanifah \& Purwanto (2013), Fathonah (2016), Sujana dkk. (2017), Fan et al. (2013) dan Helena \& Saifi (2018) yang menyatakan bahwa kepemilikan institutional berpengaruh negatif signifikan terhadap financial distress. Berdasarkan landasan teori dan hasil penelitian sebelumnya, maka hipotesis kedua dalam penelitian ini adalah sebagai berikut:

$\mathrm{H}_{3}$ : Kepemilikan Institutional berpengaruh negatif dan signifikan terhadap kemungkinan terjadinya Financialdistress. 


\section{METODE PENELITIAN}

Lokasi penelitian ini dilaksanakan pada perusahaan-perusahaan Property dan real estate di Bursa Efek Indonesia dengan mencari data Likuiditas, Leverage, dan persentase Kepemilikan Institusional untuk tahun 2013 sampai dengan tahun 2017 yang diperoleh dari bursa efek indonesia (IDX). Objek Penelitian adalah memprediksi financial distress dengan menggunakan Likuiditas, Leverage, dan Kepemilikan Institusional pada perusahaan subsektor property dan real estate di BEI tahun 2013-2017.

Rasio yang dipakai untuk mengukur likuiditas adalah current ratio yang tercantum dalam laporan keuangan perusahaan property dan real estate di BEI periode 2013-2017 dalam bentuk persentase .

$$
C \quad K=\frac{A \quad L}{K} \times 100 \%
$$

Proksi yang dipakai untuk mengukur leverage adalah Debt to AssetRatio yang diperoleh dari laporan keuangan perusahaan property dan real estate di BEI periode 2013-2017 dalam bentuk persentase.

$$
D \quad t A \quad k=\frac{T}{T A}=x 100 \%
$$

Kepemilikan institutional diukur dengan cara membandingkan kepemilikan institutional dengan jumlah saham yang beredar dari laporan keuangan perusahaan property dan real estate di BEI periode 2013-2017 dalam bentuk persentase.

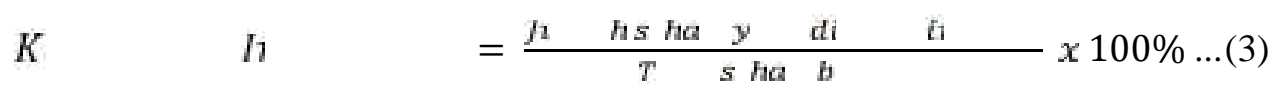


Populasi dalam penelitian ini adalah seluruh perusahaan Property dan real estate di Bursa Efek Indonesia. Populasi yang diperoleh yaitu sejumlah 47 perusahaan. Jumlah sampel dari penelitian ini adalah sebanyak 6 perusahaan yang masuk kedalam kategori mengalami financial distress dan sebanyak 30 perusahaan yang termasuk dalam kategori non financial distress. Total yang diperoleh yaitu sebanyak 36 perusahaan pada subsektor property dan real estate di BEI menjadi sampel penelitian pada tahun 2013-2017 dengan tahun basis 2015 dan 2016. Terdapat 11 perusahaan dari 47 populasi perusahaan yang tidak masuk kriteria sampel karena tidak memiliki EPS positif ataupun negatif selama 2 tahun berturut-turut pada tahun basis yang digunakan yaitu 2015 dan 2016. Pemilihan tahun 2015 dan 2016 sebagai tahun basis karena pada tahun tersebut menunjukkan konsistensi EPS perusahaan baik itu postif maupun negatif 2 tahun berturut-turut. Analisis regresi logistik digunakan dengan tujuan untuk mengetahui probabilitas variabel terikat mampu diprediksi atau dipengaruhi oleh variabel bebasnya. Model analisisnya adalah sebagaiberikut:

$\operatorname{Ln} \frac{\mathbf{P}}{[1-\mathbf{P}]}=b_{0}+b 1 \times 1+b 2 \times 2+b 3 \times 3$

Keterangan:

Ln $\frac{\mathbf{r}}{(1-\mathrm{P}]}$ : Loan dariperbandingan antara peluangfinancial distress dan peluang non financialdistress

a : Konstanta

b1 : Koefisien regresi dari Likuiditas

b2 : Koefisien regresi dari Leverage

b3 : Koefisien regresi dari Kepemilikan Institusional 


\section{HASIL DAN PEMBAHASAN}

Statistik deskriptif berkaitan dengan pengumpulan dan peringkat data yang menggambarkan karakteristik sampel yang digunakan dalam sebuah penelitian. Analisis ini berguna untuk menjelaskan karakteristik sampel terutama mencakup nilai rata-rata (mean), nilai ektrim yaitu nilai minimum dan nilai maksimum, serta standar deviasi. Berdasarkan hasil olahan SPSS, maka didapatkan nilai minimum, nilai maksimum, rata-rata (mean), dan standar deviasi dari masing-masing variabel bebas yang ditunjukkan pada Tabel 3.

Tabel 3. Statistik Deskriptif Variabel Bebas

\begin{tabular}{cccccc}
\hline & N & Minimum & Maximum & Mean & Std. Deviation \\
\hline CR & 180 & 20,770 & 1906,740 & 275,29000 & 282,713953 \\
DAR & 180 & 3,350 & 78,730 & 39,62067 & 15,551530 \\
KI & 180 &, 000 & 96,620 & 58,91444 & 25,043887 \\
Valid N (listwise) & 180 & & & &
\end{tabular}
Sumber:Data diolah, 2018

Nilai minimum dari variabel CR adalah 20,770 yang terdapat pada PT. Bukit Darmo Property Tbk pada tahun 2016, sedangkan nilai maksimum CR yakni sebesar 1906,740 terdapat pada PT. Metro Realty Tbk pada tahun 2016. Nilai rata-rata (mean) variabel CR yakni 275,29000 dengan standar deviasi sebesar 282,713953 .

Nilai minimum dari variabel DAR yakni 3,350 yang terdapat pada PT. Ristia Bintang Mahkotasejati Tbk pada tahun 2016, sedangkan nilai maksimum DAR adalah sebesar 78,730 yang terdapat pada PT. Plaza Indonesia Realty Tbk pada tahun 2017. Nilai rata-rata (mean) variabel DAR yakni 39,62067 dengan standar deviasi sebesar 15,551530. 
Nilai minimum dari variabel KI yakni 0,000 yang terdapat pada PT. Ristia Bintang Mahkotasejati Tbk pada tahun 2016 dan 2017, pada PT. Pikko Land Development Tbk di tahun 2013-2015. Nilai maksimum KI adalah sebesar 96,620 yang terdapat pada PT. Suryamas Dutamakmur Tbk. pada tahun 2017. Nilai ratarata (mean) variabel KI yakni 58,91444dengan standar deviasi sebesar 25,043887.

Penjelasan untuk variabel financial distress (Y) dapat dilihat pada Tabel berikut.

Tabel 4.

Frekuensi Variabel Terikat

\begin{tabular}{llrrrr}
\hline & & & & Cumulative \\
& & Frequency & Percent & Valid Percent & \begin{tabular}{c} 
Percent \\
\hline Valid
\end{tabular} Tidak financial distress \\
& Financial Distress & 150 & 83,3 & 83,3 & 83,3 \\
& 30 & 16,7 & 16,7 & 100,0 \\
& Total & 180 & 100,0 & 100,0 & \\
\hline
\end{tabular}

Sumber:Data diolah, 2018

Perusahaan subsektor property dan real estate yang mengalami financial distress yang diberi kode 1 dan yang tidak mengalami financial distress yang diberi kode 0 . Berdasarkan Tabel 4 terdapat 30 observasi (16,7 persen) perusahaan subsektor property dan real estate yang mengalami financial distress, sedangkan sebanyak 150 observasi (83,3 persen) perusahaan subsektor property dan real estate yang tidak mengalami financial distress selama tahun 2013-2017.

Kelayakan model pada regresi logistik dapat dinilai dengan melihat hasil Hosmer and Lemeshow Test yang digunakan untuk menguji hipotesis nol bahwa data empiris cocok atau sesuai dengan model. Dasar yang dijadikan untuk pengambilan keputusan adalah apabila nilai dari Hosmer and Lemeshow's Goodness of Fit Test statistik sama dengan atau kurang dari 0,05 maka hipoesis nol $\left(\mathrm{H}_{0}\right)$ ditolak. Hal ini berarti terdapat perbedaan antara model dengan nilai 
observasinya sehingga model yang dihipotesiskan dikatakan tidak layak karena model tidak dapat memprediksi nilai observasinya. Jika Hosmer and Lemeshow's Goodness of Fit Test statistik lebih besar dari 0,05 maka hipotesis nol $\left(\mathrm{H}_{0}\right)$ diterima sehingga dapat dikatakan bahwa model yang dihipotesiskan layak dan dapat memprediksi nilai observasinya. Hasil Hosmer and Lemeshow Test pada penelitian dapat dilihat pada Tabel 5 yakni sebagai berikut:

Tabel 5.

Hosmer and Lemeshow Test

\begin{tabular}{lllll}
\hline Step & Chi-square & Df & \multicolumn{2}{c}{ Sig. } \\
\hline 1 & 10,760 & & 8 & 216 \\
\hline Sumber $:$ Data diolah, 2018 & & & &
\end{tabular}

Model regresi logistik pada penelitian ini menunjukkan nilai statistik Hosmer and Lemeshow Test sebesar 10,760 dengan probabilitas signifikansi 0,216. Nilai signifikansi yang lebih besar dari 5\% ini menunjukkan bahwa model dalam penelitian ini dapat diterima karena cocok atau sesuai dengan data observasinya.

Keseluruhan model terhadap data dilakukan dengan membandingkan nilai antara -2 log likelihood pada awal dari hasil block number 0 dengan nilai -2 log likelihood pada akhir dari hasil block number 1. Tabel 6 dan 7 merupakan penggambaran penurunan nilai -2 log likelihood pada penelitian ini. Apabila terjadi penurunan nilai -2 log likelihood pada hasil block number 0 dan block number 1, maka model tersebut dapat dikatakan menunjukkan model regresi yang baik. Pada pengujian block number 0 dimana model regresi logistik tersebut diperoleh nilai -2 log likelihood sebesar 162,202. Apabila dibandingkan nilai -2 log likelihood pada block number 0 dengan block number 1 maka nilai tersebut mengalami penurunan yang rendah hingga mencapai nilai -2 log likelihood 
sebesar 129,162 pada block number 1. Penurunan nilai -2 log likelihood tersebut tersaji dalam tabel berikut berikut:

Tabel 6.

Iteration History ${ }^{\mathrm{a}, \mathrm{b}, \mathrm{c}}$ Block Number $=\mathbf{0}$

\begin{tabular}{llrr}
\hline Iteration & & & \multicolumn{2}{c}{$\begin{array}{c}\text { Coefficients } \\
\text { Constant }\end{array}$} \\
\hline Step 0 & 1 & $\mathbf{- 2 ~ L o g ~ l i k e l i h o o d}$ & $-1,333$ \\
& 2 & 164,227 & $-1,587$ \\
& 3 & 162,214 & $-1,609$ \\
& 4 & 162,202 & $-1,609$ \\
\hline
\end{tabular}

Sumber:Data diolah, 2018

Tabel 7. Iteration History ${ }^{\mathrm{a}, \mathrm{b}, \mathrm{c}, \mathrm{d}}$ Block Number $=1$

\begin{tabular}{llrrrrr}
\hline & & \multicolumn{4}{c}{ Coefficients } \\
Iteration & & $\mathbf{- 2 ~ L o g}$ likelihood & Constant & \multicolumn{1}{c}{ X1 } & \multicolumn{1}{c}{ X2 } & \multicolumn{1}{c}{ X3 } \\
\hline Step 1 & 1 & 139,233 &, 035 &, 001 &,- 021 &,- 015 \\
& 2 & 129,922 &, 832 &, 002 &,- 038 &,- 027 \\
& 3 & 129,171 & 1,211 &, 002 &,- 045 &,- 032 \\
& 4 & 129,162 & 1,259 &, 002 &,- 046 &,- 032 \\
& 5 & 129,162 & 1,260 &, 002 &,- 046 &,- 032 \\
\hline
\end{tabular}

Sumber:Data diolah, 2018

Kuatnya hubungan variabel independen terhadap variabel dependen dapat dilihat dari nilai Nalgelkerke $R$ Square. Tabel 8 menunjukkan nilai Nalgelkerke $R$ Square sebesar0,282. Nilai tersebut berarti bahwa variabel CR, DAR, dan KI (variabel independen) mampu menjelaskan variabel financial distress (variabel dependen) sebesar 28,2\%, sedangkan sisanya sebesar 71,8\% dijelaskan oleh variabel lain yang tidak dimasukkan dalam model persamaan regresi.

Tabel 8.

Model Summary

\begin{tabular}{lrrr}
\hline Step & -2 Log likelihood & Cox \& Snell R Square & \multicolumn{1}{c}{ Nagelkerke R Square } \\
\hline 1 & $129,162^{\mathrm{a}}$ &, 168 &, 282 \\
\hline
\end{tabular}

Sumber:Data diolah, 2018 
Model regresi yang baik yakni dengan tidak adanya gejala korelasi yang kuat diantara variabel bebasnya. Pengujian multikolinieritas dalam regresi logistik menggunakan matrik untuk melihat besarnya korelasi antara variabel bebas. Apabila nilai matrik korelasi lebih kecil dari 0,8 memiliki arti tidak terdapat gejala multikolinieritas yang serius antar variabel bebas tersebut. Pengujian multikolinieritas pada penelitian ini dapat dilihat pada Tabel 9 yang menunjukkan matrik korelasi antar variabel bebas.

Tabel 9.

Matriks Korelasi

\begin{tabular}{llrrrr}
\hline & \multicolumn{2}{c}{ Constant } & \multicolumn{1}{c}{ X1 } & X2 & \multicolumn{1}{c}{ X3 } \\
\hline \multirow{2}{*}{ Step 1 } & Constant & 1,000 &,- 506 &,- 865 &,- 673 \\
& X1 &,- 506 & 1,000 &, 427 &,- 021 \\
& X2 &,- 865 &, 427 & 1,000 &, 364 \\
& X3 &,- 673 &,- 021 &, 364 & 1,000 \\
\hline
\end{tabular}

Sumber:Data diolah, 2018

Berdasarkan hasil dari Tabel 9 menunjukkan bahwa tidak ada nilai koefisien korelasi antar variabel yang nilainya lebih besar dari 0,8 sehingga dapat disimpulkan bahwa tidak terdapat gejala multikolinearitas yang serius antar variabel bebas.

Matrik kualifikasi menunjukkan kekuatan klasifikasi terhadap observasi yang dilakukan dari model regresi untuk memprediksi terjadinya financial distress pada suatu perusahaan. Kekuatan pengelompokkan jumlah observasi dari model regresi dalam memprediksi kemungkinan terjadinya variabel terikat dinyatakan dalam persentase. Hasil tabel kualifikasi ditampilkan dalam Tabel 10.

Tabel 10. Matriks Kualifikasi

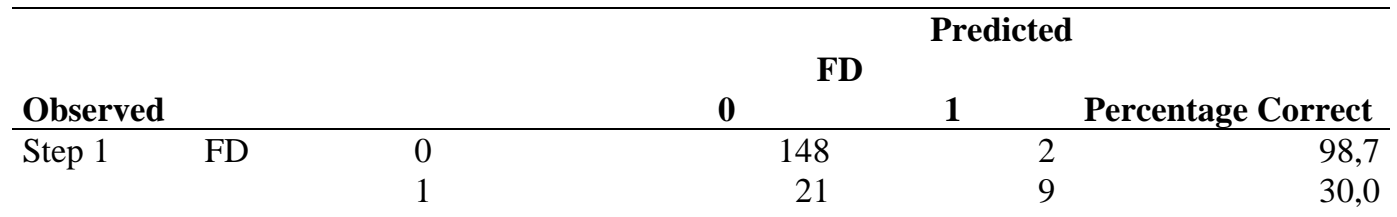


Ni Made Inten Septiani, Pengaruh Likuiditas, Leverage...

Overall Percentage

87,2

Sumber:Data diolah, 2018

Hasil analisis pada Tabel 10 menunjukkan bahwa pada baris perusahaan subsektor property dan real estate yang tidak mengalami financial distress (kode 0) dengan persentase ketepatan pengelompokan pada model ini adalah sebesar 98,7\%. Ketepatan klasifikasi pada model ini untuk perusahaan pada subsektor property dan real estate yang mengalami financial distress (kode 1) yaitu sebesar 30\%. Secara keseluruhan, ketepatan klasifikasi pada model regresi ini dalam pengelompokkan perusahaan subsektor property dan real estate yang tidak mengalami financial distress dan perusahaan yang mengalami financial distress adalah sebesar $87,2 \%$.

Uji parsial atau uji t merupakan uji yang digunakan untuk mengetahui pengaruh masing-masing variabel bebas terhadap variabel terikat secara parsial. Pada penelitian ini, jika masing-masing koefisien signifikan dari variabel bebas memiliki nilai lebih kecil dari taraf signifikansi yaitu sebesar 5\% $(0,05)$, maka dapat disimpulkan bahwa variabel bebas berpengaruh signifikan terhadap variabel terikat.

Tabel 11.

Variables in the Equation

\begin{tabular}{llrrrrrr}
\hline & \multicolumn{1}{c}{ B } & \multicolumn{1}{c}{ S.E. } & \multicolumn{1}{c}{ Wald } & Df & \multicolumn{1}{c}{ Sig. } & \multicolumn{1}{c}{$\operatorname{Exp(B)}$} \\
\hline Step 1 & X1 &, 002 &, 001 & 5,135 & 1 &, 023 & 1,002 \\
& X2 &,- 046 &, 018 & 7,021 & 1 &, 008 &, 955 \\
& X3 &,- 032 &, 009 & 11,540 & 1 &, 001 &, 968 \\
& Constant & 1,260 & 1,037 & 1,474 & 1 &, 225 & 3,524 \\
\hline
\end{tabular}

Sumber:Data diolah, 2018

Berdasarkan tabel 11 dapat dilihat bahwa nilai wald statistik dari masingmasing variabel yaitu likuiditas sebesar 5,135, leverage sebesar 7,021, dan kepemilikan institusional sebesar 11,540. Untuk menghitung nilai dari uji t dapat 
dilakukan dengan mencari akar dari masing-masing nilai wald pada variabel. Hingga didapatkan hasil pada variabel likuiditas sebesar 2,266, leverage sebesar 2,649, dan kepemilikan institusional sebesar 3,397. Untuk menghitung uji t dilakukan dengan membandingkan $t_{\text {hitung }}$ dengan $t_{\text {tabel. }}$. Taraf nyata $5 \%: 2=2,5 \%$ (uji 2 sisi) dengan derajat kebebasan (df) $n-k=180-3=177$. Dengan pengujian dua sisi (signifikansi $=1,972$ ).

Variabel likuiditas dengan nilai $t_{\text {hitung }}(2,266)>t_{\text {tabel }}(1,972)$. Dengan melihat signifikansi pada SPSS didapat nilai signifikansi $0,023<0,05$ maka variabel likuiditas berpengaruh signifikan terhadap financial distress.

Variabel leverage dengan nilai $t_{\text {hitung }}(2,649)>t_{\text {tabel }}(1,972)$. Dengan melihat signifikansi pada SPSS didapat nilai signifikansi $0,008<0,05$ maka variabel leverage berpengaruh signifikan terhadap financial distress.

Variabel kepemilikan institusional dengan nilai $t_{\text {hitung }}(3,397)>t_{\text {tabel }}(1,972)$. Dengan melihat signifikansi pada SPSS didapat nilai signifikansi $0,001<0,05$ maka variabel kepemilikan institusional berpengaruh signifikan terhadap financial distress.

Model regresi logistik dapat dibentuk dengan melihat nilai estimasi parameter dalam variables in equation pada tabel 11. Berdasarkan pada tabel 11, adapun model regresi yang terbentuk berdasarkan nilai estimasi parameter dalam variables in equation adalah sebagai berikut.

$$
\operatorname{Ln} \frac{p}{p-1}=1,260+0,002 \times 1-0,046 \times 2-0,032 \times 3
$$


Pengujian hipotesis dilakukan dengan cara membandingkan tingkat signifikansi (sig.) dengan $\alpha$ sebesar 5\%. Berdasarkan Tabel 11 maka hasil penelitian ini dapat diinterpretasikan sebagai berikut:

Variabel current ratio (CR) menunjukkan nilai koefisien regresi sebesar 0,002 dengan nilai probabilitas variabel sebesar $0,023<=0,05$. Hasil ini mengandung arti bahwa $\mathrm{H}_{1}$ ditolak karena variabel $\mathrm{CR}$ memiliki pengaruh yang positif dan signifikan terhadap kondisi financial distress padaperusahaan subsektor property dan real estate di BEI.

Hasil penelitian ini sesuai dengan penelitian Yudiawati \& Indriani (2016) yang menyatakan bahwa semakin tinggi tingkat current ratio, maka semakin tinggi pula kemungkinan perusahaan mengalami financial distress. Penelitian ini juga didukung oleh penelitian Pulungan (2017), Ufo (2015), Khaliq et al. (2014), Triwahyuningtias \& Muharam (2012) menunjukkan bahwa Current Ratio berpengaruh positif signifikan terhadap financial distress.

Variabel Debt to Assets Ratio (DAR) menunjukkan nilai koefisien regresi sebesar -0,046 dengan nilai nilai probabilitas variabel sebesar $0,008<=0,05$. Hasil ini mengandung arti bahwa $\mathrm{H}_{2}$ ditolak karena variabel DAR memiliki pengaruh yang negatif dan signifikan terhadap kondisi financial distress padaperusahaan subsektor property dan real estate di BEI.

Hasil penelitian ini sesuai dengan temuan Silalahi et al. (2018) yang melakukan penelitian pada perusahaan subsektor transportasi yang terdaftar di BEI Periode 2013-2016 menyatakan bahwa leverage yang diukur dengan debt to assets ratio berpengaruh negatif signifikan terhadap financial distress. Hasil 
penelitian yang menunjukkan DAR berpengaruh negatif signifikan berarti bahwa, nilai DAR yang tinggi tidak selalu memiliki probabilitas kebangkrutan yang tinggi tetapi juga rendah. Hal ini karena perusahaan yang memiliki tingkat utang tinggi dapat memenuhi pembelian asetnya dan meningkatkan laba perusahaan. Hasil penelitian Silalahi et al. (2018) juga didukung oleh penelitian lain yang menemukan hasil yang serupa yakni oleh Harianti (2018) dan Alifiah et al. (2013).

Variabel Kepemilikan Institusional (KI) menunjukkan nilai koefisien regresi sebesar -0,032 dengan nilai nilai probabilitas variabel sebesar $0,001<=0,05$. Hasil ini mengandung arti bahwa $\mathrm{H}_{3}$ diterima karena menunjukkan variabel $\mathrm{KI}$ memiliki pengaruh yang negatif dan signifikan terhadap kondisi financial distress padaperusahaan subsektor property dan real estate di BEI.

Hasil pengujian ini sesuai dengan temuan Helena \& Saifi (2018) yang melakukan penelitian pada perusahaan transportasi yang terdaftar di BEI tahun 2013-2016 menemukan bahwa variabel kepemilikan institusional berpengaruh negatif dan signifikan terhadap financial distress. Hasil penelitian yang dilakukan oleh Helena \& Saifi (2018) juga didukung oleh penelitian lain yang menemukan hasil yang serupa yakni oleh Cinantya \& Merkusiwati (2015), Hanifah \& Purwanto (2013), Fathonah (2016), dan Sujana dkk. (2017).

Hasil penelitian ini memiliki implikasi teoritis dan praktis. Secara teoritis hasil penelitian ini menunjukkan bahwa current ratio, debt to assets ratio, dan kepemilikan institusional memiliki pengaruh siginifikan dengan arah positif ataupun negatif terhadap kondisi financial distress perusahaan property dan real 
estate di BEI periode 2013-2017. Penelitian ini menemukan bahwa current ratio memiliki pengaruh yang positif dan signifikan dalam memprediksi financial distress. Hasil lainnya yaitu debt to asset dan kepemilikan institusionaljuga signifikan dalam memprediksi financial distress dan memiliki pengaruh yang negatif. Hasil analisis koefisien determinasi sebesar 0.282 mempunyai arti bahwa sebesar 28,2 persen informasi yang terkandung dalam data dapat dijelaskan oleh model yang digunakan dalam penelitian ini, sedangkan sisanya sebesar 71,8 persen dijelaskan oleh variabel lain yang tidak dimasukkan dalam model persamaan regresi.

Implikasi praktis dalam penelitian ini adalah bagi pihak manajemen perusahaan diharapkan dengan adanya penelitian ini maka dapat memberikan motivasi untuk meningkatkan kinerja manajemen yang tercermin dari hasil laporan keuangan perusahaan. Penelitian ini juga diharapkan agar dapat dijadikan dasar penelitian dan pertimbangan bagi para pembuat keputusan (eksekutif) dalam mengambil keputusan kedepannya dalam menanggulangi kemungkinan terjadinya financial distress yang dapat mengganggu aktivitas perusahaan. Penelitian ini dijadikan sebagai acuan dan bahan pertimbangan bagi para investor untuk menganalisis dan memilih untuk berinvestasi di perusahaan yang tepat, sehingga investor dapat meminimalkan risiko dan mengoptimalkan keuntungan yang akan dicapai.

\section{SIMPULAN}

Berdasarkan hasil analisis data dan pembahasan maka penelitian ini dapat disimpulkan bahwa dari tiga variabel yang diteli, semua variabel tersebut 
signifikan terhadap financial distress dengan arah yang negatif dan positif. Likuiditas yang diukur dengan current ratio berpengaruh positif dan signifikan terhadap financial distress. Leverage yang diukur dengan debt to assets ratio berpengaruh negatif signifikan yang menunjukkan apabila nilai utang terhadap aset yang dimiliki perusahaan semakin tinggi maka probabilitas perusahaan tersebut mengalami financial distressakan semakin semakin rendah. Kepemilikan institusional berpengaruh negatif signifikan yang berarti semakin rendah kepemilikan institusional maka probabilitas financial distress akan semakin tinggi.

Bagi pihak perusahaan hendaknya memperhatikan faktor yang memiliki pengaruh yang signifikan terhadap financial distress seperti variabel likuiditas, leverage dan kepemilikan institusional.Pengelolaan aktiva lancar yang efektif dan optimal akan dapat membayarkan kewajiban lancar suatu perusahaan, sehingga kemungkinan perusahaan mengalami kondisi financial distress akan dapat dihindari. Rasio lainnya yang harus diperhatikan oleh pihak perusahaan yaitu levergae yang diukur dengan DAR dimana perusahaan harus memperhatikan pengelolaan utang yang dimiliki. Penggunaan utang yang tinggi apabila dikelola dengan baik akan mampu membiayai pembelian aset perusahaan untuk menunjang kelangsungan aktivitas perusahaan serta penunjang persediaan. Apabila aset yang dimiliki perusahaan tinggi maka dapat mendorong perusahaan memperoleh laba yang lebih serta mampu membayar biaya-biaya tetap perusahaan.

Bagi para investor dan calon investor yang ingin berinvestasi pada perusahaan property dan real estate di BEI sebaiknya memperhatikan rasio 
keuangan perusahaan seperti likuiditasdan leverage serta kepemilikan institusional yang berpengaruh signifikan dalam memprediksi kondisi perusahaan yang mengalami financial distress, sehingga akan dapat meminimalkan risiko mengalami kerugian.

Bagi penelitian selanjutnya diharapkan untuk menggunakan lebih banyak variabel-variabel yang dapat mempengaruhi financial distress serta penelitian ini masih perlu diuji validitasnya untuk tahun-tahun mendatang.

\section{REFERENSI}

Abadi, M. T., \& Ghoniyah, N. (2016). Studi Potensi Kebangkrutan Pada Perusahaan Industri Properti Yang Go Public Di Bursa Efek Indonesia. Jurnal Riset Bisnis Indonesia, 13(1), 91-100.

Afriyeni, E. (2012). Model prediksi financial distress perusahaan. Jurnal Polibisnis Volume 4 No. 2 ISSN 1858-3717, 4(2), 1-10.

Al-khatib, H. B., \& Al-Horani, A. (2012). Predicting Financial Distress of Public Companies Listed in Amman Stock Exchange. European Scientific Journal, 8(15), 1-17. https://doi.org/http://dx.doi.org/10.19044/esj.2012.v8n15p\%25p

Alifiah, M. N., Salamudin, N., \& Ahmad, I. (2013). Prediction of financial distress companies in the consumer products sector in Malaysia. Jurnal Teknologi (Sciences and Engineering), 64(1), 85-91. https://doi.org/10.11113/jt.v64.1181

Andre, O., \& Taqwa, S. (2014). Pengaruh Profitabilitas , Likuiditas , dan Leverage Dalam Memprediksi Financial Distress ( Studi Empiris Pada Perusahaan Aneka Industri yang Terdaftar di BEI Tahun 2006-2010). Journal Wahana Riset Akuntansi, 2(1), 293-312.

Bhunia, A., Islam, S., Khan, U., \& Mukhuti, S. (2011). Prediction of Financial Distress -A Case Study of Indian Companies. Asian Journal of Business Management, 3(3), 210-218.

Carolina, V., Marpaung, E. I., \& Pratama, D. (2017). Analisis Rasio Keuangan untuk Memprediksi Kondisi Financial Distress (Studi Empiris pada Perusahaan Manufaktur yang Terdaftar di Bursa Efek Indonesia Periode 2014-2015). Jurnal Akuntansi Maranatha, 9(2), 137-145.

Cinantya, I. G. A. A. P., \& Merkusiwati, N. K. L. A. (2015). Pengaruh Corporate 
Governance, Financial Indicators, dan Ukuran Perusahaan Pada Financial Distress. E-Jurnal Akuntansi Universitas Udayana, 3(10), 897-915.

Darminto, A., \& Handayani, S. R. (2013). Pengaruh Beberapa Rasio Keuangan Terhadap Prediksi Kondisi Financial Distress (Studi pada Perusahaan Tekstil dan Garmen yang Terdaftar Di Bursa Efek Indonesia Periode 2008-2011). Jurnal Adimistrasi Bisnis, 1(2), 10-20. https://doi.org/10.1080/01402390.2011.569130

Fan, J. P. H., Huang, J., \& Zhu, N. (2013). Institutions, ownership structures, and distress resolution in China. Journal of Corporate Finance, 23, 71-87. https://doi.org/10.1016/j.jcorpfin.2013.07.005

Fathonah, A. N. (2016). Pengaruh Penerapan Good Corporate Governance Terhadap Financial Distress. Jurnal Ilmiah Akuntansi, 1(2), 133-150. https://doi.org/10.17509/jaset.v1i1.8907

Hanifah, O. E., \& Purwanto, A. (2013). Pengaruh Struktur Corporate Governance dan Financial Indicators Terhadap Kondisi Financial. Diponegoro Journal of Accounting, 2(2), 1-15.

Harianti, A. (2018). Penerapan Model Regresi Logistik untuk Memprediksi Kebangkrutan Perusahaan yang Delisting pada Bursa Efek Indonesia Periode 2011-2017. Jurnal Kompleksitas, 5(1), 40-57.

Helena, S., \& Saifi, M. (2018). Pengaruh Corporate Governance Terhadap Financial Distress (Studi Pada Perusahaan Transportasi Yang Terdaftar di Bursa Efek Indonesia Periode 2013-2016). Universitas Brawijaya Malang, 60(2), 143-152.

Hidayat, M. A., \& Meiranto, W. (2014). Prediksi Financial Distress Perusahaan Manufaktur di Indonesia. Diponegoro Journal of Accounting, 3(3), 1-11.

Irham, F. (2014). Analisis Kinerja Keuangan. Bandung: Alfabeta.

Jiming, L., \& Weiwei, D. (2011). An Empirical Study on the Corporate Financial Distress Prediction Based on Logistic Model: Evidence from China's Manufacturing Industry. International Journal of Digital Content Technology and Its Applications, 5(6), 368-379. https://doi.org/10.4156/jdcta.vol5.issue6.44

Khaliq, A., Hussein, B., Altarturi, M., Mohd, H., \& Thaker, T. (2014). Identifying Financial Distress Firms : A Case Study of Malaysia's Government Linked Companies ( GLC ). International Journal of Economic, Finance and Management, 3(3), 141-150.

Kristanti, F. T., Rahayu, S., \& Huda, A. N. (2016). The Determinant of Financial Distress on Indonesian Family Firm. Procedia - Social and Behavioral Sciences, 219, 440-447. https://doi.org/10.1016/j.sbspro.2016.05.018

Lakshan, A. M. I., \& Wijekoon, W. M. H. N. (2013). The Use of Financial 
Rations in Predicting Corporate Failure in Sri Lanka. GSTF Journal on Business Review (GBR), 2(4), 37-43. https://doi.org/10.5176/2010-4804

Laurenzia, C., \& Sufiyati. (2015). Pengaruh Kepemilikan Institusional, Ukuran Dewan Komisaris, Likuiditas, Aktivitas, Dan Leverage Terhadap Financial Distress Perusahaan Manufaktur Yang Terdaftar Di Bursa Efek Indonesia (Bei) Periode 2013-2014. Jurnal Ekonomi, 20(01), 72-88.

Lee, S., Koh, Y., \& Huh, C. (2010). Financial Distress for U . S . Lodging Industry: Effects of Leverage, Capital Intensity, and Internationalization. International CHRIE Conference-Refereed Track, (3), 2-8.

Liana, D., \& Sutrisno. (2014). Analisis Rasio Keuangan Untuk Memprediksi Kondisi Financial Distress Perusahaan Manufaktur. Jurnal Studi Manajemen Dan Bisnis, 1(2), 52-62.

Lieu, P., Lin, C., \& Yu, H.-F. (2008). Financial Early-warning Models on Crossholding groups. Journal of Industrial Management \& Data Systems, 108(8), 1060-1080. https://doi.org/10.1108/02635570810904613

Nindita, K., Moeljadi, \& Indrawati, N. K. (2014). Prediction on Financial Distress of Mining Companies Listed in BEI using Financial Variables and NonFinancial Variables. European Journal of Business and Management, 6(34), 226-237.

Ong, S. W., Choong Yap, V., \& Khong, R. W. L. (2011). Corporate failure prediction: a study of public listed companies in Malaysia. Managerial Finance, 37(6), 553-564. https://doi.org/10.1108/03074351111134745

Pulungan, K. P. A. (2017). Pengaruh Likuiditas Dan Leverage Terhadap Financial Distress Pada Perusahaan Sub Sektor Keramik , Porselen Dan Kaca Yang Terdaftar Di Bursa Efek. Jurnal Financial, 3(2), 1-9.

Saleh, A., \& Sudiyatno, B. (2013). Pengaruh Rasio Keuangan Untuk Memprediksi Probabilitas Kebangkrutan Pada Perusahaan Manufaktur yang Terdaftar di Bursa Efek Indonesia. Dinamika Akuntansi Keuangan Dan Perbankan, 2(1), $82-91$.

Sastriana, D. (2013). Pengaruh Corporate Governance Dan Firm Size Terhadap Perusahaan Yang Mengalami Kesulitan Keuangan (Financial Distress). Diponegoro Journal of Accounting, 2(3), 1-10.

Setiawan, H., \& Amboningtyas, D. (2018). Financial Ratio Analysis For Predicting Financial Distress Conditions (Study on Telecommunication Companies Listed In Indonesia Stock Exchange Period 2010-2016). Jurnal Manajemen Universitas Pandanaran, 4(4).

Silalahi, H. R. D., Kristanti, F. T., \& Muslih, M. (2018). Pengaruh Rasio Keuangan Dan Ukuran Perusahaan Terhadap Kondisi Kesulitan Keuangan (Financial Distress) Pada Perusahaan Sub-Sektor Transportasi yang Terdaftar di Bursa Efek Indonesia (BEI) Periode 2013-2016. E-Proceeding of 
Management, 5(1), 796-802.

Simanjuntak, C. (2017). Pengaruh Rasio Keuangan Terhadap Financial Distress (Studi Pada Perusahaan Transportasi yang Terdaftar di Bursa Efek Indonesia Periode 2011-2015). E-Proceeding of Management, 4(2), 1580-1587.

Sujana, E., Putri, M. R. C., \& Kuniawan, P. S. (2017). Pengaruh Struktur Corporate Governance dan Ukuran Perusahaan Terhadap Kesulitan Keuangan Pada Perusahaan Property dan Real Estate yang Terdaftar di Bursa Efek Indonesia. E-Journal S1 Ak Universitas Pendidikan Ganesha, 8(2).

Triwahyuningtias, M., \& Muharam, H. (2012). Analisis Pengaruh Struktur Kepemilikan, Ukuran Dewan, Komisaris Independen, Likuiditas dan Leverage Terhadap Terjadinya Kondisi Financial Distress (Studi Pada Perusahaan Manufaktur yang Terdaftar di Bursa Efek Indonesia Tahun 20082010). Diponegoro Journal of Accounting, 1(1), 1-14.

Ufo, A. (2015). Determinants of Financial Distress in Manufacturing Firms of. Research Journal of Finance and Accounting, 6(17), 9-17.

Wahyuningtyas, F. (2010). Penggunaan Laba dan Arus Kas untuk Memprediksi Kondisi Financial Distress (studi kasus pada perusahaan bukan bank yang terdaftar di Bursa Efek Indonesia periode tahun 2005-2008). Skripsi, Universitas Diponegoro.

Waqas, H., \& Md-rus, R. (2018). Predicting financial distress : Applicability of Oscore and logit model for Pakistani firms. Journal of Business and Economic Horizons, $14(2)$, 389-401. https://doi.org/http://dx.doi.org/10.15208/beh.2018.28 Predicting

Widhiari, N. L. M. A., \& Merkusiwati, N. K. L. A. (2015). Pengaruh Rasio Likuiditas, Leverage, Operating Capacity, dan Sales Growth Terhadap Financial Distress. E-Jurnal Akuntansi Universitas Udayana, 11(2), 456469.

Yudiawati, R., \& Indriani, A. (2016). Analisis Pengaruh Current Ratio, Debt To Total Asset Ratio, Total Asset Turnover, Dan Sales Growth Ratio Terhadap Kondisi Financial Distress. Diponegoro Journal of Management, 5(2), 1-13. 